\title{
Determinants of Non-Performing Loan in Nepalese Commercial Banks ${ }^{1}$
}

\author{
Seema Bhattarai ${ }^{2}$
}

\begin{abstract}
The non-performing loans (NPL) of financial institutions are considered as a significant issue in the context of Nepal for last few decades. The paper aims to identify the impact of macroeconomic variables (GDP, Inflation, and Real Effective Exchange Rate) and bank specific variables (size, change in loan, real lending rate of interest, and share of loan to total assets) on the non-performing loan of the commercial banks in Nepal. The study was conducted mainly with secondary sources. The data were collected for 26 commercial banks covering the period of 2002-2012 with 227 observations. The study found that macroeconomic variables such as the real effective exchange rate have significantly negative impact on non-performing loan. The impact of GDP growth rate was found to be insignificant in this study. One year lagged inflation rate has significant positive impact on non-performing loan. The banks which charge relatively higher real interest rate have higher non-performing loan, which is consistent with the findings of previous studies. The ownership dummy has positive coefficient and significant at one percent level showing that if the bank is government owned the non-performing loan would be higher than that of the private owned banks. As well, more lending in the previous years and current year reduces the non-performing loan since the coefficient of change in loan in current and previous years have negative coefficient and significant at one percent level.
\end{abstract}

Keywords: Non-performing loan, Commercial banks, Inflation, Gross Domestic Product, Assets

\section{BACKGROUND}

Financial institution is an institution which collectsfunds from the public and places them in financial assets, such as deposits, loans, and bonds, rather than tangible property. To be specific, bank is a financial intermediary accepting deposits and granting loans that offers the widest menu of services of any financial institution. The various

1 The paper is the outcome of MBA Dissertation submitted to, Uniglobe college, Pokhara University. The author wish to thank Prof. Dr. Radheshyam Pradhan, Associate Professor Tara Bhusal, Dr. Chakra Khad$\mathrm{ka}$ and Dr. Nara Bahadur Bista for their valuable suggestions during the research work. The paper is the revised version of the paper presented in the International Workshop on Banking and Finance organized by Nepal Rastra Bank, 2015. The author is benefitted from the comments and suggestions received during the workshop.

2 Faculty in Arunima Campus, Arunima Education Foundation, Affiliated to Tribhuvan University Nepal. She is available on seemabhattarai1@gmail.com 
functions of banks are carrying out currency exchanges, discounting commercial notes and making business loans, offering deposits services(saving deposits), safekeeping of valuables, supporting government activities like credit, granting consumer loans, financial advising, cash management, offering equipment leasing among others (Rose \& Hudgins, 2010).

It is observed that the bank credit depends upon the activity. As economy grows bank credit accelerates while the slow growth of the economic activity or the decline in economic activity results decline in bank credit. Hence it is widely accepted that bank credit exhibits pro-cyclicality (Dash \& Kabra, 2010). The pro-cyclical trend of the bank credit can be explained with the help of many factors. The supplier of the credit (bankers) may feel high credit risk during the slowdown of the economy and may provide fewer score. While during expansionary situation the banks may evaluate credit with high score and may find less risky and there will be higher expansion of credit.

Macroeconomic theory tells us that expansionary situation creates optimistic environment and recession or declining phase may generate pessimistic environment in the business (Mankiw, 2011). Hence business people will demand more credit for their investment activities during the expansionary phase of the economy while they may be reluctant to invest and reduce the demand of credit during contractionary phase of the economy (Dash \& Kabra, 2010).

Financial institutions are very important in the economic growth of the economy as they help to make easy credit flow and enhance economic activity with increasing investment in productive sectors of the economy (Richard, 2011). Sound financial sector is more important for the economic growth of any country (Rajaraman \& Visishtha, 2002). Commercial banks are the major source of credit for business firms and households in many countries (Rose, and Hudgins, 2010). Better performance of these financial institutions play a significant role for the economic prosperity of any country and poor performance of these institutions result the slowdown of economic growth and affects badly to the region of the world. Since "the NPA of banks is an important criterion to assess the financial health of banking sector" (Ahmed, 2010), identification of the potential problem and close monitoring is paramount importance for the better performance of this sector. Banking crisis exists in the country if the nonperforming assets (NPAs) touch 10 percent of GDP. The loss of income from NPAs not only brings down the level of income of the banks but also hinders them from quoting better lending rates (Khan\& Bishnoi, 2001). 
Studies also found that an increase in the riskiness of loan assets is rooted in the bank's lending policy adductive to relatively unselectively and inadequate assessment of sectoral prospects (Sergio, 1996). Banking business is exposed to various risks such as credit risk, liquidity risk, interest risk, market risk, operational risk and management risk. However, credit risk stands out as the most detrimental to them all (Iyer, 1999). The risk of erosion in asset value due to simple default or non-payment of interest and principal of dues by the borrowers is credit or default risk (Sharma, 1996).

Rapid credit growth, which was associated with lower credit standards contributed to higher loan losses in certain states in the USA (Keeton, 1999). Studies in Argentinean banking system found that non-performing loans (NPLs) are affected by both bank specific factors and macroeconomic factors (Bercoff et al., 2002). Studies found that the real growth in GDP, rapid credit expansion, bank size, capital ratio, market power were found as explanatory variables for non-performing loans in Spanish commercial and saving banks (Salas \& Saurina, 2002). Similarly Jimerrez and Saurina (2006), by examining the Spanish banking sector, provide evidence that non-performing loans are determined by GDP growth rate, real interest rate and lenient credit terms. This study further shows that lenient credit terms result the herd behavior and agency problem that may entice bank managers to lend excessively during boom periods. It has also been viewed that bank's lending policy could have crucial influence on nonperforming loans (Reddy, 2004).

An effective risk management is central to good banking and the tradeoff between risk and return is one of the prime concerns of any investment decision whether long term or short term and effective credit risk management allows a bank to reduce risks and potential NPAs. Once a bank understands their risks and their costs, they will be determining their most profitable business, thus price products according the risk. Therefore, the bank must have an explicit credit risk strategy and support by organizational changes, risk management technique and fresh credit process and systems. The non-performing loans (NPL) of financial institutions are considered as a significant issue in the context of Nepal for last few decades. The immediate consequence of large amount of NPLs in the banking system is bank failure. Many researches on the cause of bank failures find that asset quality is a statistically significant predictor of insolvency and that failing banking institutions always have high level of non-performing loans prior to failure (Barr \& Siems, 1994).

There is no standard form to define non-performing loans globally. Variation may exist in terms of the classification system, the scope, and contents as per country. As a regulatory financial institution of Nepal, the central bank, that is, Nepal Rastra 
Bank has classified the loan basically into the pass loan, sub-standard loan, doubtful loan and loss or bad loan. Pass loan is that type of loan whose interest or principal payments are less than three months in arrears. Sub-standard loans whose interest or principal payments are longer than three months in arrears of lending conditions are eased. Doubtful is liquidation of outstanding debts appears doubtful and the accounts suggest that there will be a loss, the exact amount of which cannot be determined. Loss loans are regarded as not collectable, usually loans to firms which applied for legal resolution and protection under bankruptcy laws. Pass loans are under the category of performing loans whereas sub-standard loan, doubtful loan and loss loan are under the non-performing loans (NRB, 2013)

Considering these facts it is necessary to control non-performing loans for the economic growth in the country, otherwise the resources can be jammed in unprofitable projects and sectors which not only damages the financial stability but also the economic growth. In order to control the non-performing loans it is necessary to understand the root causes of these non-performing loans in the particular financial sector (Rajaraman \& Visishtha, 2002). If we look into the causes of great recession 2007-2009 which damaged not only economy of USA but also economies of many countries of the world find that non-performing loans were one of the main causes of this recession (Richard, 2011).

Exploring the determinants of ex-post credit risk is an issue of substantial importance for regulatory authorities concerned with financial stability and for banks' management. The ex-post credit risk takes the form of non-performing loans (NPLs). Reinhart and Rogoff (2010)point out those NPLs can be used to mark the onset of a banking crisis. In most of the past studies, that investigate the determinants of NPLs either macroeconomic or bank-specific determinants (but not both) are used as explanatory variables (Louzis et al., 2012). Rinaldi et al. (2006) analyze household NPLs for a panel of European countries and provide empirical evidence that disposable income, unemployment and monetary conditions have a strong impact on NPLs. Berge and Boye (2007)find that problem loans are highly sensitive to the real interest rates and unemployment for the Nordic banking system over the period 1993-2005. Boss et al. (2009)examine the coupling of credit risk of the main Austrian corporate sectors with the business cycle. Segoviano et al., (2006) focus on the macroeconomic variables to understand the determinants of non-performing loan.

Literatures also analyze the effect of bank specific characteristics on non-performing loan. Berger and DeYoung (1997)draw attention to the links between bank-specific characteristics and focus on efficiency indicators and problem loans. Specifically, 
this study formulate possible mechanisms, namely 'bad luck', 'bad management', 'skimping' and 'moral hazard', relating efficiency and capital adequacy. They test the derived hypotheses for a sample of US commercial banks spanning the period from 1985 to 1994 and conclude that, generally, decreases in measured cost efficiency lead to increased future problem loans.

The success of commercial banks depends on profitability. Loan is the major component of earning assets of commercial banks. However, the profitability will be more if the bank have less non-performing loan. On the other hand if the non-performing loan is high the banks may not be able reap profit instead they may be in loss because the bank need to put reserves for the amount of non-performing loans (Farhan et al., 2012). The three letters NPA strike terror in banking sector and business circle today. The dreaded NPA rule says simply this: when interest or other due to a bank remains unpaid for more than 90 days, the entire bank loan automatically turns a non performing asset (Barth et al., 2004). The recovery of loan has always been problem for banks and financial institution (Goyal \& Kaur, 2011). Borio and Lowes (2002) estimate that the output loss due to banking crisis was about two digit percentage of GDP. Downturn of national economy, insider lending, political connection of bank owners, failure of disclosure of vital information by customers and lack of proper skills of the banking staff are found as some of reasons of increase in non-performing loans in and banks by different studies (Wareru \& Kalani, 2009; Richard, 2011).

In Nepal, commercial banks have a mushrooming growth in the last two decades. The number of commercial bank have risen to 31 at present with 1425 branches and it occupies a share of about $77 \%$ of the total asset/liabilities of banks and financial institutions in Nepal (NRB, 2012). Nepal is also facing banking crisis and some of the bank and financial institutions have already failed during last few years and are in the process of liquidation (Sapkota, 2011). Studies show that the failure of banks in Nepal was also the result of the high non-performing assets, lending without differentiating markets, products and borrowers' credit worthiness and excessive loan exposure to real estate (Sapkota, 2011).

The amount of non-performing loan is one of the indicators of performance of the economy. Less the NPL, better the financial health of the economy. If the nonperforming loan is more, there will be poor financial health and crisis may result in the economy. In the past before 2001, Nepal bank limited and RBBL nearly collapsed due to high non-performing loan of over fifty percent of their total assets. Because of which NRB with the support of IMF and World Bank adopted a reform program (Ahikary et al., 2007). 
Thus the paper aims to analyze the factors influencing non-performing loan in Nepal specially the macro-economic variables (inflation, GDP, real effective exchange rate and real interest rate) and bank specific variables (size of the bank, change in assets, and loans).

\section{REVIEW OF PREVIOUS STUDIES}

There are few literature in India and in Europe which analyze the sensitivity of nonperforming loans to macroeconomic and bank specific factors (Das \& Kabra, 2010; Beck et al., 2011; Louzis et al., 2012). The study of Dash and Kabra (2010) employs panel data set of six commercial banks of India covering 10 years (1998/99-2008/09). It includes macroeconomic variables like inflation rate, real effective exchange rate and annual growth rate of Gross Domestic Product (GDP) as the explanatory variables to effect non-performing loan in India. The study found that the real effective exchange rate had a strong positive impact on the level of non-performing loans and growth in real GDP had inverse relationship with non-performing loan. However, the size of the bank and inflation are not important determinants of NPL in the Indian commercial banking system (Dash \& Kabra, 2010).

Similarly Louzis et al. (2012) analyzed the macroeconomic and bank specific determinants of non-performing loans in the banking sector of Greece using quarterly data of 2003-2009. In this study the macroeconomic variables, specifically the real GDP growth rate, the unemployment rate, the lending rates and public debt were considered as the explanatory variable to effect on the level of NPLs. In case of banks specific variables performance (measured by ROE), efficiency (measured by the ratio of operating expenses and operating income), and category of loan were the major explanatory variables to effect non-performing loan.

On the other hand Beck et al. (2011) reviewed the trends in the credit quality of banks' loan books over the past decade, measured by non-performing loans, based on an econometric analysis for a panel of 80 countries. This study considered the main explanatory variables as real GDP growth rate, Real Effective Exchange rate and equity prices.

In Nepal, there are not any scientific study regarding the impact of macroeconomic and banks specific variables on non-performing loan. Some studies aimed to evaluate the financial sector reforms adopted after 1990 (Bhetuwal, 2005). Since this reform has its objective to reduce the pile of non-performing loan by prudent loan appraisal and improved monitoring mechanism it may have some importance for the reduction 
of non-performing loan in Nepal. Study show that lack of ability of the bankers to properly assess the impact of economic indicators on the growth and sustainability of the business, lack of proper knowledge among the bankers for the evaluation of project idea and management of the project and incompetence to properly assess the exit modality as and when necessary were the main internal factors contributing for non-performing loan.

During past few decades, many banks both in developed, emerging and developing economies face difficult situation and problems in performance. Such bank failure and financial distress have affected many banks and some of which have closed down by the regulatory authorities (Richard, 2011).

Nepal is also facing banking crisis and some of the bank and financial institutions have already failed during last few years and are in the process of liquidation (Sapkota, 2011). Studies show that the failure of banks in Nepal was also the result of the high non-performing assets due to and the result of lending without differentiating markets, products and borrowers' credit worthiness and excessive loan exposure to real estate (Sapkota, 2011).

There is about NRs. 16,325 million NPL within the commercial banks of Nepal (NRB, 2012). Though this is about $3 \%$ of the total loan it varies among the banks from $0.6 \%$ to about $7.27 \%$. The share of non-performing loan to total loan is high (above $5 \%$ ) in case of government owned banks than the private sector banks. Hence this study aims to find out the macroeconomic (GDP growth rate, Inflation rate \& real effective exchange rate) and banks specific determinants (size, loan to asset ratio, total assets, ownership dummy, real interest rate) of non-performing Loans in commercial Banks of Nepal.

\section{METHODOLOGY}

The study is mainly based on the secondary information. The secondary information is collected from almost all the commercial banks that have the data on non-performing loan is available. Hence the secondary data is gathered for 26 out of 32 commercial banks of Nepal. Remaining banks are new and the information on the non-performing loan is not yet available for the study period. The data for the said banks are collected and analyzed for the period of 2002/3 to 2011/12. The secondary information is collected from the published documents of the commercial banks and Nepal Rastra Bank. The data from Quarterly Economic Bulletin and Banking and Financial Statistics published by Nepal Rastra Bank and Various Economic Survey published by Ministry of Finance, 
Government of Nepal are utilized for the purpose of the study. The information is also collected from the balance sheet and annual reports of selected commercial banks and used for purpose of the study.

Commercial banks having at least 10 years of working experience were selected for the purpose of the study. It is because only these banks may have non-performing loan. Newly established banks may not have non-performing loan. Thus only 26 commercial banks having at least 10 years of working experience were selected for the purpose of the study.

Following the model adapted by Dash and Kabra (2010) the study is conducted with the following econometric model.

\section{Econometric Model}

This study applies a multiple regression equation to test the effect of selected explanatory variables on the non-performing loan of the sampled banks. The regression model is based on the literature by Dash and Kabra (2010). The data for this analysis is collected from the secondary sources and is analysed on the basis of the following function and equation:

Non-Performing Loan $=\mathrm{f}$ (Size, natural logarithm of ratio of loan to assets, change in Loans in the current year, change in loan in the previous year, real interest rate in the current year, real interest rate in the previous year, annual inflation rate of current and previous year, growth rate of GDP in the current and previous year, real effective exchange rate in the current and previous year, ownership dummy)

From the above function the following equation can be specified for the estimation of the coefficient of the explanatory variables.

$$
\begin{aligned}
& \operatorname{lnNPLA}_{\mathrm{it}}=\beta_{0 \mathrm{i}}+\beta_{1} \operatorname{lnLA} \mathrm{it}_{\mathrm{it}}+\beta_{2} \mathrm{SIZE}_{\mathrm{it}}+\beta_{3} \Delta \mathrm{LOANS}_{\mathrm{it}}+\beta_{4} \Delta \mathrm{LOANS}_{\mathrm{it}-1}+\beta_{5} \mathrm{RIR}_{\mathrm{it}}+\beta_{6} \mathrm{RIR}_{\mathrm{it}-1}+ \\
& \beta_{7} \operatorname{lnINF}_{\mathrm{t}}+\beta_{8} \operatorname{lnINF} \mathrm{t}-1+\beta_{9} \Delta \mathrm{GDP}_{\mathrm{rt}}+\beta_{10} \Delta \mathrm{GDP}_{\mathrm{rt}-1}+\beta_{11} \operatorname{lnREER}_{\mathrm{t}}+\beta_{12} \operatorname{lnREER}_{\mathrm{t}-1}+\text { Ownership } \\
& \text { dummy }+\varepsilon_{\text {it }} \\
& \text { with } \mathrm{i}=1, \ldots, \mathrm{N}, \mathrm{t}=1, \ldots \mathrm{T} \text {; and }{ }_{\text {it }}^{\varepsilon} \mathrm{N}|| \mathrm{D}\left(0, \sigma^{2}\right)
\end{aligned}
$$


where,

LnNPL_Ait and lnNPL_A ${ }_{\text {it- } 1}$ represent the natural log of the ratio of NPLs to total loans for bank $\mathrm{i}$ in year $\mathrm{t}$ and $\mathrm{t}-1$;

$\triangle \mathrm{GDP}_{\mathrm{rt}}$ and $\triangle \mathrm{GDP}_{\mathrm{rt}-1}$ represent the annual growth in real GDP at time $\mathrm{t}$ and t-1respectively;

$\mathrm{RIR}_{\mathrm{it}}$ and $\mathrm{RIR}_{\mathrm{it}-1}$ denote the real interest rates measured as the difference between the weighted average lending rate and the annual inflation rate) at time $t$ and $\mathrm{t}-1$;

$\operatorname{lnREER} \mathrm{t}_{\mathrm{t}}$ and $\operatorname{lnREER_{\mathrm {t}-1}}$ indicates the natural log of the real effective exchange rate at time $t$ and $t-1$;

$\operatorname{lnINF}_{t}$ and $\operatorname{lnINF} \mathrm{t}_{\mathrm{t}-1}$ indicate the natural $\log$ of the annual inflation rate at time $t$ and $\mathrm{t}-1$;

$\mathrm{SIZE}_{\mathrm{it}}$ is the ratio of the relative market share of each bank's assets that capture the size of the institution at time $t$;

$\operatorname{lnL} \mathrm{A}_{\mathrm{it}}$ is the natural $\log$ of the loans to total asset ratio for bank $\mathrm{i}$ in year $\mathrm{t}$;

$\triangle \mathrm{LOANS}_{\mathrm{it}}, \triangle \mathrm{LOANS}_{\mathrm{it}-1}$ represent the growth in loans for bank $\mathrm{i}$ in year $\mathrm{t}$, and $\mathrm{t}-1$ respectively;

and $^{\varepsilon}$ it is the error term. Some of the variables will be converted into natural logs.

Because the selected explanatory variables may affect the dependent variable after some period of time, the variables are entered in the model in lagged form.

The data on bank wise NPL is available only from Mid-July 2003. Hence the present study covers 10 year, that is, Mid July 2003 to Mid-July 2012 in most of the banks' data. Table 1 shows the detail of the variables used in Model I. 
Table 1: Definition of Variables, Expected Sign and Possible Reasons for Model I

\begin{tabular}{|c|c|c|c|c|}
\hline Factor Context & $\begin{array}{l}\text { Variable } \\
\text { Name }\end{array}$ & Calculation & $\begin{array}{l}\text { Expected } \\
\text { Impact }\end{array}$ & Reasons \\
\hline $\begin{array}{l}\text { Dependent } \\
\text { Variable }\end{array}$ & $\mathrm{NPLA}_{\mathrm{it}}$ & $\begin{array}{l}\mathrm{NPL}_{\mathrm{it}} / \text { total } \\
\text { loans }\end{array}$ & & \\
\hline
\end{tabular}

Explanatory Variables

$L A_{i, t} \quad$ Loans $_{\mathrm{it}} /$ Assets $_{\text {it }} \quad$ +ve

Size $_{\text {it }}$ (relative market share of

Asset $_{\text {it }} / \sum$ Asset $_{\text {it }}$

Ambiguous

Bank I at time t.)

$\triangle \mathrm{GDP}_{\mathrm{rt}}$ (The

$$
\left(\mathrm{GDP}_{\mathrm{t}}-\mathrm{GDP}_{\mathrm{t}-1}\right) / \mathrm{GDP}_{\mathrm{t}-1} \quad-\mathrm{ve}
$$

annual growth

rate in real GDP at

time $t$ )
RIR $_{\text {it }}$ (Real Interest

Rate of bank I at

time $t$ )

$\mathrm{INF}_{\mathrm{t}}$ (Inflation at

time $t$ )

Weighted average lending +ve rate of bank $\mathrm{i}$ at time $\mathrm{t}$ -annual inflation rate at time $\mathrm{t}$

$\left(\mathrm{CPI}_{\mathrm{t}}-\mathrm{CPI}_{\mathrm{t}-1}\right) / \mathrm{CPI} \mathrm{t}_{\mathrm{t}-1}+\mathrm{ve}$

REER $_{t}$ (real effective Real exchange rate with IC +ve

exchange rate)

$\triangle$ Loans $_{\text {it }}$ $\$ *$ trade share with rest of the world

$$
\text { Loans }_{\text {it }} \text {-Loans }_{\text {it-1 }} / \text { Loans }_{\text {it-1 }} \text { Ambiguous }
$$

Ownership Dummy Government owned

+ve bank $=1$, otherwise 0

Higher the share of loan to total assets higher will be the possibility of NPL.

Larger the size of the bank better the risk management strategies and superior loan portfolio. On the other hand there is also possibility that larger banks have more lending and may have more NPL.

Higher growth in GDP indicates better performance of the economy and business. Hence there will be better repayment and low NPL

Higher the real interest rate higher will be the cost of borrowing to business and higher will be the NPL

Higher the inflation rate higher will be the cost of the business, which ultimately may result less return from the business and low capacity to repay loan and higher will be the NPL.

Normally higher exchange rate may result higher imports and less exports and low performance of the national business and higher NPL.

Excessive lending may result more NPL on the other hand more additional lending may help productive outcome and may help to reduce NPL.

Government owned banks have more NPL than other banks 


\section{FINDINGS}

The major macroeconomic variables that affect the non-performing loan are the inflation rate, growth rate of GDP, Real Effective Exchange Rate and the bank specific variables are size of the bank, change in loan, lending rate etc. Three models are developed to understand the impact of macroeconomic and bank specific variables on non-performing loan.

Table 2: Descriptive Statistics of Macroeconomic and Bank Specific Variables

\begin{tabular}{llll}
\hline Variables & Mean & $\begin{array}{l}\text { Std. } \\
\text { Deviation }\end{array}$ & N \\
\hline Ratio of NPL to total Loan & 6.63 & 11.45 & 227 \\
Annual growth rate of real GDP & 3.93 & 1.11 & 227 \\
Weighted average lending rate & 8.96 & 2.41 & 227 \\
Rate of change in Loan & 23.19 & 29.93 & 202 \\
Asset of individual bank/total asset of commercial banks & 4.63 & 4.55 & 227 \\
Ownership dummy & .13 & .34 & 227 \\
REER & 116.8 & 10.5 & 227 \\
Inflation rate & 7.7 & 2.81 & 227 \\
Ratio of loan to total assets & 58.5 & 15.0 & 227 \\
RIR & 1.26 & 2.87 & 227 \\
Natural log of NPL_A & .93 & 1.48 & 216 \\
Natural log of L_A & 4.02 & .34 & 227 \\
Natural log of inflation & 1.97 & 0.40 & 227 \\
Natural log of REER & 4.76 & .09 & 227 \\
Lagged Rate of change in loan & 25.2 & 30.49 & 175 \\
Lagged real interest rate & 1.14 & 2.98 & 201 \\
Lagged natural logarithm of Inflation & 1.93 & 0.41 & 201 \\
Lagged natural logarithm of REER & 4.75 & .09 & 201 \\
Lagged real growth rate of GDP & 3.85 & 1.15 & 201 \\
Non-Performing Loan & 1103.2 & 2578.70 & 227 \\
Loan amount & 13964 & 10066.47 & 227 \\
Asset of the bank & 26931 & 22318.82 & 227 \\
\hline
\end{tabular}

Source: Author's from data calculation based on NRB, 2012 and Annual Reports of Related Banks

Similarly in the second model only lagged variables are used for the regression analysis. The third model is developed by dropping all the lagged variables. 
The descriptive statistic of the variables used in all of the four models is presented in table 1 . The table shows that the total number of observations is 227 for the variables. However for the lagged and natural logarithm variables the number of observations is decreased. The mean value of NPL to total loan (dependent variable) is 6.63. Similarly, the mean value of ratio of loan to total assets is 58.51. Similarly, the variable, size has the average value of 4.63.The mean value of weighted real interest rate is 1.25 , and weighted average lending rate is 8.96 . The mean value of GDP growth rate, REER, and inflation rate are 3.93, 116.7 and 7.7 respectively. The mean and standard deviation of other variables along with their number of observations are shown in Table 2.

\section{Multiple Regression Result}

The OLS estimates of equation (1) which seeks to find the impact of macroeconomic and bank specific variables on non-performing loan is given in Table 3.

Table 3: OLS Results; Dependent Variable: Natural Logarithm of Ratio of NPL to Total Loan

\begin{tabular}{llll}
\hline Explanatory variables & Model I & Model II & Model III \\
\hline Constant & 21.13 & $36.135^{* * *}$ & 45.319 \\
lnLAit & $2.76^{* * *}$ & & \\
Sizeit & -0.024 & -0.019 & -0.032 \\
Aloanit & $-0.020^{* * *}$ & & $-0.032^{* * *}$ \\
Aloanit-1 & $-0.007^{* * *}$ & $-0.015^{* * *}$ & \\
RIRit & 0.023 & & $0.118^{* * *}$ \\
RIRit-1 & $0.208^{* * *}$ & $0.185^{* * *}$ & \\
lnINFt & -0.294 & & -0.116 \\
lnINFt-1 & 0.975 & $1.171^{* *}$ & \\
GDPrt & -0.057 & & 0.020 \\
GDPrt-1 & -0.033 & -0.046 & \\
lnREERt & 4.602 & & $-9.093^{* * *}$ \\
lnREERt-1 & $-10.417^{* *}$ & $-7.628^{* *}$ & $1.888^{*}$ \\
Ownership dummy & $1.454^{* * *}$ & $1.807^{* * *}$ & $1.888^{* * *}$ \\
R-square & 0.624 & 0.528 & 0.596 \\
Adj.R-square & 0.591 & 0.506 & 0.579 \\
F-statistics & 18.841 & 23.110 & 34.679 \\
\hline
\end{tabular}

** Significant at $5 \%$ level. ${ }^{* * *}$ Significant at $1 \%$ level

Source: Author's estimate from SPSS software using data from Banking and Financial Statistics of NRB and Annual Reports of Sampled Banks 
Results given in Table 3 show that in model I the coefficient of natural logarithm of loan to assets is positively and significantly related with the natural logarithm of ratio of non-performing loan to assets is positively and significantly related with the natural logarithm of ratio of non-performing loan to total assets. This indicates that both move in the same direction i.e. as the loan to asset ratio increases the non-performing loan to total assets.

The coefficient of loan growth rate and lagged loan growth rate are significant at 1 percent level of significance. The sign of the coefficient is negative indicating that more increase in loan results the decrease in NPL. Hence to reduce the non-performing loan the growth of loan must be higher in the previous year and current year. It may be because additional loan may have productive outcome and may have caused decrease in NPL. The major amount of NPL lie with the government owned banks due to the ineffective management of 80 's and 90 's. Hence the recent lending of last10 years may have a positive impact as these banks adopted the banking sector reform programs with the support of World Bank and International Monetary Fund and they have made a policy shift in lending and monitoring mechanism, due to which, the lending during these years, change in loan may have positive impact on non-performing loan. Hence it is found that the change in loan during the current year and previous year both have negative impact on NPL i.e. increase in loan may result the decrease in NPL.

There is also a provision of renewal and restructuring the loan by which bank will convert the non-performing loan as performing loan with a fresh loan. Hence the change in loan in the current year and previous year has negative and significant impact in NPL.

Similarly the lagged real interest rate has positive impact on non-performing loan and is significant at 1 percent level of significance, which is consistent with prior study. This indicates that higher interest rate increases the non-performing loan.

The coefficient of natural logarithm of lagged real effective exchange rate is negative and significant at $5 \%$ level of significance. This indicates that increase in lagged real effective exchange rate may result decrease in non-performing loan of the commercial banks may be due to the reason that the exchange rate with IC is pegged and the trade share with India is highest and the lagged REER may have positive impact on performance of borrowers and might have caused reduction in non-performing loan.

The ownership dummy has positive and significant impact on the non-performing loan. The dummy was taken whether the bank is government owned or not. Table 3 shows that it has a coefficient of 1.454 which indicates that if the bank is government 
owned, the one percent point change will cause $1.454 \%$ increase in non-performing loan.

From Table 3 it is clear that there exist a positive and significant relationship between real interest rate and the non-performing loan of commercial banks of Nepal (Model III). Increase in real interest rate (RIR) result the increase in cost of fund which leads to the decrease in repayment capacity of loan. Thus, the non-performing loan also increases with the increase in real interest rate. This finding is consistent with our hypothesis and theory.

The macroeconomic variable like growth rate of GDP has no significant impact on the non-performing loan. These findings are inconsistent with the findings of Dash and Kabra (2010). In Nepal the single largest share of GDP comes from the agriculture sector and the performance of the agriculture sector basically depends on monsoon. If the monsoon is good the performance of the agriculture sector will be better and the GDP growth rate will be high. On the contrary if there is poor monsoon, the performance of the agriculture sector will be poor and the GDP growth rate will be low. Commercial banks of Nepal lend very insignificant amount in agriculture sector hence the performance of GDP may not have any significant effect on the non-performing loan.

Inflation in Nepal is mostly affected by the inflation in India. The study shows that Nepal's inflation is influenced by the inflation in India (NRB, 2011) and hence its impact on the repayment of the borrowers of the commercial banks will be insignificant and the impact on non-performing loan may be insignificant. The finding is consistent with the findings of Dash and Kabra (2010).

The value of $R^{2}$ is 0.624 . Here, the adjusted $R$ square is 0.591 which shows that the $59.1 \%$ of the sample variation in non- performing loan is explained by the independent variables. The $\mathrm{F}$ test is a measure of the overall significance of the estimated regression. Here, the value of F-statistics is 18.841 and is significant at $1 \%$ level of significance. Hence the overall model is significant. In the remaining two models the value of $\mathrm{R}^{2}$, adjusted $\mathrm{R}^{2}$ and the $\mathrm{F}$ statistics is not much difference.

\section{CONCLUSION}

Macroeconomic variables such as the real effective exchange rate have significantly negative impact on non-performing loan. The impact of GDP growth rate is found to be insignificant in this study which. One year lagged inflation rate has significantly positive impact on non-performing loan (Model II). The bank which charge relatively 
higher real interest rate have higher non-performing loan. Similarly the change in loan rate of the previous year has significantly negative impact on non-performing loan. As there is higher increase in loan of the previous year non-performing loan will decrease significantly. If the bank is government owned bank the non-performing loan would be higher than that of the private owned banks.

\section{References}

Adhikary, D. K., Pant, R., \& Dhungana, B. R. (2007). Study on financial sector reform in Nepal. Prepared for south Asian network of economic institutes (SANEI). Institute of development Economics. Quaid -i-Azam University, Islamabad, Pakistan.

Ahmed, J. Ud-Din. (2010). An empirical estimation of loan recovery and asset quality of commercial banks. The North Eastern Hill University (NEHU) Indian Journal, $8(1)$.

Ahmed, J.U. (2008). Asset quality and non-performing assets of commercial banks. New Delhi: MD Publication Pvt. Ltd.

Barr, R. L. S. \& Siems, T. (1994). Forecasting banking failure: A non-parametric frontier estimation approach. Researches Economiques de Lovain, 60,417-429.

Barth, J.R., Caprio, G., \& Levine, R. (2004). Bank regulation and supervision: What works best? Journal of Financial Intermediation, 13, 205-248.

Beck, R., Jakubik, P., \& Pilou, A. (2011). Asset quality and macroeconomic performance: What role for the exchange rate and stock prices? European Central Bank Working Paper, December, 2011.

Bercoff, J.J., Giovanniz, J. diEGrimardx, F. (2002).Argentineanbanks, credit growth and the tequila crisis: A duration analysis.

Berge, T.O., \& Boye, K.G. (2007). An analysis of bank's problem loans. Norges Bank Economic Bulletin 78, 65-76.

Berger, A., \& DeYoung, R. (1997). Problem loans and cost efficiency in commercial banks. Journal of Banking and Finance, 21, 849-870.

Bhetuwal, K.R. (2005). Assessing the effectiveness of financial sector reforms in Nepal. Maharaja Sayajirao University Baroda, Vadodara, Unpublished Ph.D Dissertation.

Borio, C., \& Lowe, P. (2002). Assessing the risk of banking crisis. BIS Quarterly Review, $43-54$ 
Boss, M., Fenz, G., Pann, J., Puhr, C., Schneider, M., Ubl, E. (2009). Modeling credit risk through the Austrian business cycle: An update of the OeNB Model. OeNB Financial Stability Report 17, 85-101.

Dash, M. K., \& Kabra, G. (2010). The determinants of non-performing assets in Indian commercial bank: An econometric study. Middle Eastern Finance and Economics, 7, 94-106. Extracted from http://www.swatee.org/swatee-in-Media

Farhan, M., Sattar, A., Chaudhary, A.H., \& Khalil, F. (2012).Economic determinants of non-performing loans: Perception of Pakistani bankers. European Journal of Business Management4 (12), 87-99

Iyer, T. N. A. (1999). Bank supervision and the management of non-performing advances. The Journal of the Indian Institute of Bankers, 7-9.

Jiménez, G., \& Saurina, J. (2006). Credit cycles, credit risk and prudential regulation. International Journal for Central Banking, 2 (2), 65-98.

Keeton, W.R. (1999). Does faster loan growth lead to higher loan losses? Economic Review, Second Quarter. Federal Reserve Bank, Kansas City.

Khan, M. Y., \& Bishnoi, T.R. (2001). Banking crisis and financial reforms: Lessons for India. Chartered Secretary, (pp.44-48).

Louzis D. P., Vouldis, A. T., Metaxas, V. L. (2012). Macroeconomic and bank specific determinants of non-performing loans in Greece: A comparative study of mortgage, business and consumer loan portfolios. Journal of Banking and Finance, 36, 1012-1027.

Mankiw, N.G. (2011). Principles of macroeconomics ( $4^{\text {th }}$ ed., $\quad$ Eighth Indian reprint.): Cengage Learning

NRB. (2011). Comparative analysis of inflation in Nepal and India. Baluwatar, Kathmandu: Nepal Rastra Bank, Research Department.

. (2012). Bank supervision Report, Baluwatar, Kathmandu: Bank Supervision Department, Nepal Rastra Bank.

.(2012). Banking and financial statistics. Mid-July, 2012, No. 58.Baluwatar, Kathmandu: Nepal Rastra Bank, Bank and Financial Institution Regulation Department, Statistics Division. . (2013). Consolidated directives. Baluwatar, Kathmandu: Author

Rajaraman, I., \& Vashistha, G. (2002).Non-performing loans of Indian public sector banks - Some panel results. Economic \& Political Weekly, 37, 429-435. 
Rajaraman, I., Bhumik, S., \& Bhatia, N. (1999). NPA Variations across Indian commercial banks: Some findings. Economic \& Political Weekly, 34, (3/4), 161-168.

Reddy, Y.V. (2004). Credit policy, systems, and culture. Reserve Bank of India Bulletin, March, 2004.

Reinhart, C., \& Rogoff, K. (2010). From financial crash to debt crisis. (NBER Working Paper 15795).

Richard, E. (2011). Factors that cause Non-performing loans in commercial banks in Tanzania and strategies to resolve them. Journal of Management Policy and Practice, 12(7), 50-58.

Rinaldi, L., \& Sanchis-Arellano, A. (2006). Household debt sustainability: What explains household non-performing loans? An empirical analysis. (ECB Working Paper).

Rose, P.S., \& Hudgins, S.C. (2010) Bank management and financial services. Delhi: Tata McGraw-Hill Education Private Limited.

Salas, V., \& Saurina, J. (2002). Credit risk in two institutional regimes: Spanish commercial and savings banks. Journal of Financial Services Research, 22, 203224.

Sapkota, C. (2011). Nepalese banking crisis explained. Journal of Institute of chartered Accounts of Nepal, 13, 4

Sarma, R. H. (1996). Product market risk (default /credit risk). The Journal of the Indian Institute of Bankers, 61-65.

Segoviano, M., Goodhart, C., \& Hofmann, B. (2006). Default, credit growth, and asset prices. (IMF Working Paper WP 06/223).Washington DC: International Monetary Fund.

Sergio, M. (1996).Non-performing bank loans: Cyclical patterns and sectoral risk. Review of Economic Conditions in Italy. Rome: Jan-Jun 1996, Issue 1. 